\title{
Bone metabolism and bone mineral density in adolescent idiopathic scoliosis
}

\author{
Ko Ishida ${ }^{1 *}$, Yoichi Aota ${ }^{2}$, Naoto Mitsugi', Tomoyuki Katsuhata', Takayuki Higashi ${ }^{3}$ Katsutaka Yamada ${ }^{3}$, \\ Tomoyuki Saito ${ }^{3}$ \\ From The 10th Meeting of the International Research Society of Spinal Deformities (IRSSD 2014 Sapporo) \\ Sapporo, Japan. 29 June - 2 July 2014
}

\section{Objective}

To characterize bone metabolism in AIS patients using bone metabolism markers.

\section{Summary of background data}

Although osteopenia is often associated with AIS, bone metabolism in this condition has not been assessed.

\section{Methods}

Bone mineral density (BMD) of the lumbar spine and bilateral proximal femurs (dual energy $\mathrm{x}$-ray absorptiometry) and bone metabolism markers (bone formation marker: serum bone alkaline phosphatase (BAP); bone resorption marker: serum tartrate-resistant acid phosphatase serum band 5 (TRAP5b)\} were measured in 55 consecutive AIS subjects aged 10 to 18 years-old (mean: $15.6+/-1.7)$. BMD, body mass index (BMI), and age of menarche were compared between subjects with normal and high values of TRAP5b.

\section{Results}

Nineteen subjects (34\%) had osteopenia and 17 subjects (31\%) had osteoporosis. In 51 AIS subjects (93\%), values for BAP were within normal range, while 33 subjects $(60 \%)$ had high values for TRAP5b. Subjects with high values for TRAP5b had BMDs of the lumbar spine significantly lower than BMDs of patients with normal values of TRAP5b.

\section{Conclusions}

The primary cause of low BMD in AIS was increased bone resorption.

${ }^{1}$ Yokohama City University Medical Center, Japan

Full list of author information is available at the end of the article
Authors' details

${ }^{1}$ Yokohama City University Medical Center, Japan. ${ }^{2}$ Yokohama Brain and Stroke Center, Japan. ${ }^{3}$ Yokohama City University, Japan.

Published: 19 January 2015

doi:10.1186/1748-7161-10-S1-P7

Cite this article as: Ishida et al:: Bone metabolism and bone mineral density in adolescent idiopathic scoliosis. Scoliosis 2015 10(Suppl 1):P7.
Submit your next manuscript to BioMed Central and take full advantage of:

- Convenient online submission

- Thorough peer review

- No space constraints or color figure charges

- Immediate publication on acceptance

- Inclusion in PubMed, CAS, Scopus and Google Scholar

- Research which is freely available for redistribution
C Biomed Central 